PROBLEMY WCZESNEJ EDUKACJI / ISSUES IN EARLY EDUCATION

ISSN 1734-1582

Aniela Różańska

https://doi.org/10.26881/pwe.2019.45.04

ORCID: 0000-0003-2891-9361

Uniwersytet Śląski

aniela.rozanska@us.edu.pl

\title{
Pluralizm religijny wyzwaniem dla wczesnej edukacji
}

\section{Summary}

\section{Religious pluralism as a challenge for early education}

In the article the question of religious pluralism is presented. The author gives the characteristics of this concept, which has changed its meaning over the recent years. The author brings into light some contemporary ways of perception of the religious pluralism and controversies they result in. The concept of inclusive pluralism by Jacques Dupuis has been recommended by the author as a model of religious pluralism which enables the opening of religious education on the inter-religious dimension. A proper understanding of religious pluralism plays an important role in forming an open religious identity which is one of the key tasks in education including early education.

Keywords: religious pluralism, perception of pluralism, religious identity, early education

Słowa kluczowe: pluralizm religijny, postrzeganie pluralizmu, tożsamość religijna, wczesna edukacja

\section{Wprowadzenie}

Pluralizm jest jedną z kluczowych kategorii współczesnej kultury i życia społecznego. Stanowi też ważne zagadnienie w pedagogice międzykulturowej. Aby uwypuklić różnicę znaczeniową między pluralizmem atradycyjnym zróżnicowaniem, podaję definicję pluralizmu za Peterem L. Bergerem: „Pluralizm to sytuacja, w której różne grupy etniczne lub religijne współistnieją w warunkach spokoju społecznego i utrzymują wzajemne kontakty społeczne" (Berger 2007: 8). Zatem na pluralizm składa się nie samo występowanie, lecz współistnienie różnych grup, które wzajemnie się kontaktują, podtrzymując porządek (spokój) w układzie społecznym i terytorialnym.

Pluralizm jest postrzegany, rozumiany oraz oceniany w różny, czasami bardzo odmienny sposób, w zależności od traktowania go jako faktu społeczno-kulturowego, idei bądź wartości. Opinie i oceny normatywne dotyczące tego, czym współcześnie jest bądź powinien być pluralizm oraz jaką przypisuje się mu wartość, są zdecydowanie rozbieżne ze względu na przekonania aksjologiczne, tradycje intelektualne i doświadczenia kulturowe autorów tych opinii. Rozumienie pluralizmu różnicuje się szczególnie mocno, kiedy rozważane są przemiany tożsamości kulturowej i religijnej w kontekście kulturowych i światopoglądowych odmienności poszczególnych środowisk, jak też uczestników dyskursu. 
Problem staje się jeszcze bardziej złożony w wypadku pluralizmu religijnego, kiedy na kwestię pluralizmu nakłada się kwestia religii, niosąca własny bagaż dylematów definicyjnych. Zróżnicowanie zjawisk religijnych i problem z ich zdefiniowaniem prowadziły nawet do propozycji odrzucenia pojęcia religii i zastąpienia go badaniem treści przeżycia wyznawców (Smith 1964: 48). Tak się jednak nie stało, miejsce religii w świecie i nauce zostało ugruntowane. Nowy sposób widzenia obecności religii w przestrzeni publicznej zaproponował Peter L. Berger (2012: 313-316), zastępując teorię sekularyzacji, jako zbyt upraszczającą rzeczywistość, teorią pluralizacji religii. Zachodni świat chrześcijański, reprezentowany przez stanowisko papieża Franciszka, a wcześniej Jana Pawła II, proponuje w sytuacji pluralizmu religijnego stosowanie dialogu i postawy wsłuchiwania się w potrzeby i pragnienia Innego (inaczej myślącego, wierzącego bądź niewierzącego), a nie konfrontację czy prozelityzm.

W polskim dyskursie naukowym nad pluralizmem religijnym nie były w pełni doceniane jego obecność i znaczenie dla religijności Polaków. Obecnie coraz częściej do głosu dochodzą ci, którzy w pluralizmie upatrują przede wszystkim źródła zagrożeń związanych z rozmywaniem tożsamości chrześcijańskiej (Słotwińska 2014), którzy przekonują, że idea pluralizmu jako wartości i wynikająca z niej idea międzykulturowa muszą zostać zmienione. Jest to tym bardziej niezrozumiałe, że według danych Eurostatu z 2018 roku Polska ma jeden z najniższych wskaźników imigrantów w Europie (mniej niż 1\% ludności).

\section{Sposoby percepcji i rozumienia pluralizmu religijnego}

Pluralizm religijny jest różnie rozumiany i definiowany w przestrzeni naukowego dyskursu, jak również bardzo zróżnicowana jest jego percepcja społeczna wytworzona na podstawie specyfiki społeczno-kulturowej wiedzy i wyobrażeń podzielanych na jego temat. W niniejszym artykule przedstawiłam różnorakie sposoby postrzegania pluralizmu religijnego - w tym koncepcję Geira Skeiego i koncepcję Jacques'a Dupuis'a. Ważnymi akcentami są - po pierwsze - traktowanie pluralizmu religijnego jako stanu rzeczywistego, wynikającego z wielości kultur i religii oraz - po drugie - odczytanie pluralizmu jako wartości (w tym wartości pedagogicznej).

Pluralizm religijny jest częścią naszej rzeczywistości, tak samo realną jak wielość kultur, ras, narodów i grup etnicznych. Pluralizmu religijnego jako rzeczywistości de facto nie można negować, można tylko różnie się do niego odnosić, postrzegając go i oceniając bardziej lub mniej pozytywnie. Geir Skeie rozróżnia dwa typy pluralizmu: tradycyjny i nowoczesny (Skeie 1995: 84-91). Tradycyjny pluralizm tworzy zauważalna kulturowa i religijna różnorodność obecna $\mathrm{w}$ społeczeństwie, wynikająca zarówno $\mathrm{z}$ odmiennych religijnych sposobów życia mieszkańców wraz z różnorodnością lokalnych znaczeń symboli i obyczajów, jak i z coraz większej obecności imigrantów, którzy przynoszą swój bagaż kulturowy, religijny i własne obyczaje. Nowoczesny pluralizm należy wiązać z różnorodnym klimatem intelektualnym - używając określenia Anthony’ego Giddensa - 
„wysokiego modernizmu” (high modernism) czy postmodernizmu, w którym pluralizm dużych grup światopoglądowych został zasilony pluralizmem jednostek. Społeczeństwa, w których panował pluralizm grup, przekształciły się w społeczeństwa indywidualistyczne, składające się z silnie zindywidualizowanych jednostek o wysokim poziomie samoświadomości (Brezinka 2005: 93). Heterogeniczność jednostki dotyczy zarówno jej światopoglądu, jak i stylu życia.

Nowoczesną różnorodność religii tworzą zarówno poszczególne religie i wyznania zinstytucjonalizowane, jak i różne formy religii prywatnej, będące wynikiem indywidualnego konstruowania (bricolage) światopoglądu z dostępnych jednostce elementów tradycji religijnych i magicznych. Pierwszym formom towarzyszy spadek znaczenia, drugim - wzrastająca popularność. Nowe formy religii Thomas Luckmann nazwał „niewidzialną religią" (1967) w przeciwstawieniu do „widzialnych” i łatwo rozróżnialnych form instytucjonalnych. Są to zmiany plasujące się bardziej w świadomości jednostki niż w obszarach społecznych. W tym kontekście należy rozumieć przemiany religijności zachodzące w społeczeństwach europejskich, w których większość ludzi przestaje się identyfikować z tradycyjnymi Kościołami, co nie znaczy, że różne formy religijności/duchowości nie odgrywają w ich życiu roli.

Postrzeganie pluralizmu religijnego warunkuje postawę wobec ludzi innych religii. Niebezpieczne - pod względem konsekwencji - są przede wszystkim dwa sposoby postrzegania pluralizmu religijnego: indyferentyzm i fundamentalizm. Indyferentyzm jako obojętność wobec zjawiska pluralizmu religijnego sprawia, że nasze postrzeganie rzeczywistości jest niepełne, nie zauważamy bądź nie chcemy widzieć jednej z ważnych cech różnicujących społeczeństwa i jednostki, a co za tym idzie - nasza postawa wobec innych religii może być niewłaściwa, niedoceniająca (bądź oceniająca tylko z punktu widzenia naszej religii) tego, co dla danej religii może być bardzo ważne. Postawa fundamentalistyczna natomiast sprawia, że jednostka postrzega pluralizm religijny jako zło, uważając tylko własną religię za prawdziwą i jedynie dobrą, co prowadzi do nierozwiązywalnego konfliktu z tymi, którzy nie podzielają jej zasad. Karen Armstrong (1998: 404-406) szkicuje pesymistyczny scenariusz przyszłości religii, wskazując na wzrost fundamentalistycznych tendencji $\mathrm{w}$ ramach chrześcijaństwa, przejawiających się $\mathrm{w}$ dosłownym traktowaniu przesłania religijnego i w całkowitym braku tolerancji wobec tych, których uważają za „nieprzyjaciół Boga”, czyli żydów, muzułmanów oraz przedstawicieli wszystkich religii wschodnich. Fundamentalistyczne postawy występują we wszystkich wielkich religiach świata, również w ideologiach świeckich.

Hans-Georg Ziebert, teolog i pedagog niemiecki, zadaje pytanie: „W jaki sposób religie mają się uporać z pluralizmem, jeżeli każda z nich uważa, iż posiada pewnego rodzaju »monopol na prawdę«? Ażeby przedstawić warunki, jakie musi spełniać chrześcijańska dydaktyka edukacji religijnej, musimy zdecydować, jak mówić o Chrystusie jako o Zbawicielu wszystkich, podczas gdy jesteśmy skazani na różnorodność. Należy postrzegać wielość nie jako problem, ale bardziej jako zadanie, które trzeba rozwiązać, i wyzwanie, któremu trzeba sprostać" (Ziebert 2001: 13). 


\section{Inkluzywny pluralizm religijny (koncepcja zasadniczego pluralizmu Jacques'a Dupuis'a)}

W opozycji do pluralizmu religijnego, który często jest odbierany negatywnie, istnieją dwie inne możliwości: ekskluzywizm (zakłada wyłączną wartość i prawdziwość jednej religii i odrzucanie innych) i inkluzywizm (przyjmuje, że inne religie są nośnikami pewnych wartości, które zasługują na włączenie w system wartości chrześcijańskich). W teologii katolickiej przez stulecia, aż do Soboru Watykańskiego II, dominował paradygmat ekskluzji, czyli przekonanie, że gwarancją zbawienia jest przynależność do Kościoła katolickiego, paradygmat zamknięty na jakikolwiek dialog z pozostałymi religiami. Opcja inkluzywistyczna, będąca konsekwencją uzgodnień Soboru Watykańskiego II (1962-1965) oraz deklaracji Nostra aetate, prowadzi do nowego, pozytywnego spojrzenia Kościoła na inne religie. Inkluzywizm nie tylko istnieje jako koncepcja teologiczna czy filozoficzna, ale również polityczna. Jak zauważa Jürgen Habermas, w społeczeństwach wielokulturowych zaostrza się problem dyskryminacji mniejszości (etnicznych, wyznaniowych, językowych czy form życia) i jednym z możliwych rozwiązań jest inkluzja „wrażliwa na różnice” (Habermas 2009: 150), polegająca przede wszystkim na zapewnieniu autonomii kulturalnej, szczególnych praw grupowych, polityce równouprawnienia i innych instrumentów służących ochronie mniejszości.

Ekskluzywny typ rozumienia innych religii formalnie już dzisiaj nie występuje ani w Kościele katolickim, ani w innych Kościołach chrześcijańskich. Był charakterystyczny dla przedsoborowego sposobu myślenia o innych religiach (Figl i in. 2010: 15-47), ale elementy tych poglądów można spotkać w wypowiedziach próbujących uzasadnić wyjątkowość chrześcijaństwa. W sytuacji odrzucenia ekskluzywizmu inkluzywizm pozostaje podejściem alternatywnym. Interpretacja inkluzywna przyznaje, że zbawienie może być dostępne także $\mathrm{w}$ innych religiach, dostrzega $\mathrm{w}$ religiach niechrześcijańskich elementy zbawcze, uznaje jednak wyjątkowość religii chrześcijańskiej, a Chrystusa uważa za jedynego Pośrednika i drogę do zbawienia (stanowisko chrystocentryczne). Podejście inkluzywistyczne umożliwia dyskusję o poznawczej funkcji religii i dzięki swemu umiarkowaniu nie prowadzi do konfrontacji i konfliktów religijnych.

Inkluzywny pluralizm religijny - ta koncepcja belgijskiego teologa Jacques'a Dupuis'a zasługuje na rekomendację, stanowi ona bowiem radykalną zmianę w sposobie postrzegania innych religii i wyznań. Jako połączenie inkluzywizmu z pluralizmem nie dotyczy płytkiego i skrajnego modelu pluralizmu, polegającego na założeniu: „wiele dróg - wiele celów”, lecz raczej odpowiada tezie „wiele dróg - jeden wspólny cel”. Zamiarem Dupuis'a było pogodzenie wyznawanej w Kościołach chrześcijańskich wiary w Jezusa Chrystusa jako uniwersalnego Zbawiciela z pozytywnym - zbawczym znaczeniem innych religii, wynikającym z zamiarów Boga wobec ludzkości i ekonomii Jego działań w świecie. Teolog przyjmuje pluralizm religijny jako pozytywny de principio, świadczący o bogactwie objawienia się Boga na różne sposoby. Różne religie, zdaniem Dupuisa, nie tyle są wyrazem wysiłków w poszukiwaniu Boga przez człowieka, ile wska- 
zują na różnorodne sposoby wychodzenia Boga naprzeciw człowiekowi. Teolog szuka racji bytu pluralizmu religii jako takiego. Czy istnieje zbieżność i wzajemne ubogacenie się tradycji religijnych świata mimo ich różnic, oryginalności i osobliwości? Pytanie, na które autor odpowiada pozytywnie, nie wynika jedynie z teologicznej spekulacji, ale kształtuje się wewnątrz społeczeństwa pluralistycznego, gdzie każda religia funkcjonuje w kontekście wieloreligijnym. (Dupuis czterdzieści lat pracował w pluralistycznych religijnie i etnicznie Indiach jako misjonarz i wykładowca. Bezpośredni kontakt z przedstawicielami innej kultury, tradycji i ,innej koncepcji Boga i człowieka” oraz doświadczenie - praxis dialogu - stworzyły podstawę nowego paradygmatu).

Autor wskazuje na wzajemną komplementarność i zbieżność pomiędzy tajemnicą Chrystusa w chrześcijaństwie, będącą fundamentem wiary chrześcijańskiej (Dupuis 1999: 193), oraz innymi tradycjami religijnymi. Wacław Hryniewicz uważa, że najbardziej cenną myślą zawartą w koncepcji Dupuis’a jest przekonanie, że: „chrześcijańska wiara w Chrystusa jako jedynego i powszechnego Zbawiciela ludzkości da się pogodzić $\mathrm{z}$ uznaniem pozytywnej roli i znaczenia innych tradycji religijnych $\mathrm{w}$ zbawieniu swoich wyznawców" (Hryniewicz 2003: 11). Dupuis przekonuje, że Bóg przemawiał w różnych tradycjach religijnych do całej ludzkości, gdyż swoje zbawienie ofiarował wszystkim ludziom (Dupuis 2003: 167-169). Oznacza to, że inne religie mogą być pomocne dla swoich wyznawców w odkrywaniu Bożego planu względem ludzkości i w doświadczeniu tajemnicy zbawienia (Dupuis 2003: 224).

Pomiędzy chrześcijaństwem a innymi religiami istnieje wzajemna komplementarność, choć jest ona asymetryczna, dzięki niej może zachodzić między nimi wymiana i dzielenie się wartościami, dynamiczna interakcja i wzajemne wzbogacanie się (Dupuis 2003: 341). Dlatego - zdaniem Dupuisa - teologia chrześcijańska pluralizmu religijnego powinna być oparta na wzajemnym oddziaływaniu na siebie wiary chrześcijańskiej i innych żywych wiar i powinna być w tym sensie teologią „,międzyreligijną”. Żadna religia, również chrześcijaństwo, nie może zawłaszczać innych religii. Chrześcijaństwo nie posiada prawdy absolutnej, jedynie uznaje i jest „w drodze ku prawdzie” objawionej przez Chrystusa w historii świata (Dupuis 2002: 11). Tylko Bóg jest rzeczywistością w pełni absolutną, którego pełnia ma wymiar eschatologiczny, nie historyczny (por. Geffré 1996: 25). Takie ujęcie, zgodne z deklaracją Nostra aetate, ogłoszoną w 1965 r. w czasie Soboru Watykańskiego II, nie pozbawia znaczenia innych tradycji religijnych, wskazuje, że prawda jest obecna także w innych religiach, pozwala je szanować jako swoiste sposoby wyrażania tej samej prawdy religijnej.

Koncepcja inkluzywnego pluralizmu religijnego Dupuis'a jest nie tylko chrześcijańskim sposobem widzenia i rozumienia pluralizmu religijnego, ale też kompetentnym teologicznym uzasadnieniem potrzeby dialogu międzyreligijnego jako wyrazu globalnej moralnej odpowiedzialności, zwłaszcza w kontekście problemów i potrzeb współczesnego człowieka. Stanisław Obirek (2011: 268) koncepcję zasadniczego pluralizmu Jacques'a Dupuis'a nazywa „kopernikańskim zwrotem” w teologii, polegającym na odwrocie od tradycyjnego pojmowania chrześcijaństwa jako religii wykluczenia i ukazaniu go jako 
religii otwartej na inne tradycje religijne. Niemniej koncepcja inkluzywnego pluralizmu religijnego, przedstawiona przez Dupuis'a w umiarkowany i kompetentny sposób, miała jednoznaczny charakter chrystocentryczny.

Współcześnie, kiedy chrześcijaństwo utraciło swą dominującą pozycję i funkcjonuje w kontekście wielokulturowym wewnątrz pluralistycznych społeczeństw, uzasadnionym posunięciem jest akceptacja stanowiska inkluzywnego pluralizmu, w którego świetle poza chrześcijaństwem - w różnych tradycjach religijnych i światopoglądowych - istnieje bogactwo elementów prawdy i dobra. Powinnością chrześcijaństwa, afirmującego i nawiązującego do tego faktu, jest szukanie punktów wspólnych, które mogą się stać „mostami łączącymi różne religie". Wezwanie Dupuis'a do otwarcia się teologii na szerszy wymiar „międzyreligijny” jest również zachętą dla pedagogiki i edukacji religijnej do otwarcia się na międzyreligijny wymiar i do umiejscowienia - przynajmniej niektórych - jej zadań w perspektywie edukacji międzyreligijnej i międzykulturowej.

\section{Inkluzywny pluralizm religijny jako wartość pedagogiczna/edukacyjna}

Pluralizm rozumiany jako wartość pedagogiczna to pluralizm postrzegany jako zadanie umożliwiające właściwe jego rozumienie. W teorii pedagogicznej panuje zgoda na równouprawnienie wielu paradygmatów poznawczych, a więc na istnienie przeciwstawnych sobie racji, sposobów myślenia czy odczuwania. Pluralizm edukacyjny odwołuje się do dialogu i jest formą otwartości na inność. Jest zatem przyzwoleniem na organizacyjne i programowe zróżnicowanie rzeczywistości i edukacji szkolnej (Kotusiewicz 1995: 91), w tym również nauczania religii, na przemianę jej monogeniczności i przejście od dualistycznego podziału rzeczywistości „my” - „oni” do wieloaspektowości i wielowarstwowości. Inkluzywizmu i pluralizmu religijnego domagał się Bogusław Milerski, proponując ponad dwie dekady temu wprowadzenie - jako alternatywy dla dominującego w polskiej edukacji modelu konfesyjno-katechumenalnego - ponadkonfesyjnego (integralnego i otwartego na dialog pedagogiczny, ekumeniczny i światopoglądowy) modelu szkolnej edukacji religijnej (Milerski: 1998).

Rozważając inkluzywny pluralizm religijny jako wartość pedagogiczną, można przypisać mu następujące cechy:

- kształtuje się w procesie nawiązywania i pogłębiania relacji osobowych z ludźmi o odmiennych postawach i przekonaniach religijnych, nie jest „dany z góry” ani narzucony instytucjonalnie;

- relacje te są zarazem płaszczyzną kształtowania i wzbogacania własnej tożsamości religijnej;

- nie zakłada z góry równości i prawdziwości wszystkich religii (co u wierzących może się spotkać z sprzeciwem);

- przez odwoływanie się do konkretnych przykładów, sytuacji dnia codziennego i doświadczenia własnego zachęca uczniów, by przez porównanie swoich prze- 
konań i wyznawanych prawd wiary z zasadami i praktykowaniem wiary innych próbowali zastanowić się nad racjonalnością prawd Innych (Davis 2010: 189);

- przez próbę dostrzeżenia działań Boga w innych religiach kształtuje postawę szacunku wobec religii niechrześcijańskich i rozwija własną tożsamość religijną bez niebezpieczeństwa relatywizowania chrystianizmu;

- jest warunkiem edukacji do dialogu ekumenicznego (międzywyznaniowego) i międzyreligijnego;

- jako kategoria praktyki edukacyjnej umożliwia proces przemiany nauczania religijnego z monokonfesyjnego w międzykonfesyjny, poszerzony o kształtowanie kultury religijnej, postaw tolerancyjnych i dialogicznych wobec religijnej i światopoglądowej inności;

- jest wyznacznikiem edukacji religijnej młodzieży, którą można określić jako międzykulturową edukację religijną.

\section{Po co pluralizm religijny w edukacji religijnej?}

Współczesny pluralizm - w opinii badających go socjologów - znacząco oddziałuje na kształtowanie tożsamości religijnej i dokonuje w niej istotnych zmian. Pluralistyczny wymiar religijny rzeczywistości społeczno-kulturowej Europy warunkuje, wręcz wymusza, potrzebę budowania takiej tożsamości religijnej, która gwarantowałaby bardziej pozytywne postrzeganie i postawy wobec Innych, odmiennych religijnie. Taki typ tożsamości nazywa się otwartą tożsamością religijną (Hryniewicz 1994; Różańska 2017: 172-181). Otwarta tożsamość religijna jest tożsamością kształtowaną nie w opozycji do Innych religijnie, lecz poprzez traktowanie ich tożsamości jako źródła dopetnienia $i$ wzbogacenia własnej. Nie chodzi tu - jak się czasem uważa - o rozmywanie tożsamości religijnej, ale o jej wzbogacenie poprzez wzajemną wymianę wartości, co w wypadku tożsamości chrześcijańskiej prowadzi, zdaniem ekumenistów, do pełnej tożsamości chrześcijańskiej (Hryniewicz 1994: 7), do scalania wartości duchowych, będących wspólnym dobrem chrześcijaństwa jako całości (Hryniewicz 1997: 167-168), a w kontekście różnych religii jest mediacją między wartościami chrześcijańskimi i pozytywnymi wartościami innych religii.

Kształtowanie tożsamości religijnej jest zadaniem i procesem przebiegającym w ciągu całego życia, jednak w trakcie edukacji religijnej małego dziecka proces ten rozpoczyna się i powinien być wspomagany i wzmacniany przez osoby znaczące: rodziców, nauczycieli, katechetów czy wychowawców. Zadania edukacji religijnej w kontekście kształtowania tożsamości religijnej tradycyjnie obejmują: nabywanie wiedzy o własnej religii i Kościele, formację w danej religii/wyznaniu, czyli wprowadzanie w życie religijne oraz rozwijanie postaw związanych z danym wyznaniem. Niemniej brakuje treści nauczania, których zamieszczenia w edukacji religijnej domaga się pluralistyczny wymiar religijny rzeczywistości, dotyczy to między innymi problematyki: wielości/ inności wierzeń, poznania Innego religijnie - jego przekonań religijnych, przyjmowa- 
nych wartości i wynikającego z nich stylu życia. Stąd szkolna edukacja religijna, nawet w środowiskach wielowyznaniowych, w znikomym stopniu wspomaga nabywanie postawy otwartości wobec inności religijnej i kształtowanie otwartej tożsamości religijnej. Pluralizm jawi się bardziej jako wyzwanie (zagrożenie?) niż droga wyjścia z impasu. Kwestie polityki edukacyjnej, zależne od poszczególnych Kościołów, determinują hierarchię rozważanych w programach nauczania tematów, powodując, że treści dotyczące pluralizmu religijnego są ujmowane zbyt powierzchownie i marginalnie (Różańska 2015: 472-473).

\section{Pluralizm religijny jako zadanie wczesnej edukacji dziecka}

Przyjęcie tezy, że pluralizm religijny jest zadaniem, a nie zagrożeniem dla tożsamości, implikuje podjęcie refleksji na temat, w jaki sposób i w jakich obszarach wczesnej edukacji pluralizm jest bądź może być obecny. Kluczowym kontekstem, w którym docenienie pluralizmu jawi się jako niezbędne, jest rozwijanie w uczniu poczucia własnej tożsamości, otwartej na inne kultury/religie, na Innego w wymiarze religijnym/światopoglądowym. Kontekst ten pojawia się nie tylko w edukacji religijnej, ale też w obszarze edukacji obywatelskiej, międzykulturowej i regionalnej.

Jak wcześniej zaznaczono, jednym z podstawowych celów wczesnej edukacji - w obszarach edukacji religijnej, obywatelskiej, międzykulturowej i regionalnej - jest rozwijanie w uczniach poczucia własnej tożsamości, co z kolei wymaga m.in. kształtowania tożsamości pluralistycznej, czyli poznawania siebie z uwzględnieniem własnej odmienności i kreowania postaw otwartych, tolerancyjnych, nastawionych na różnorodność ludzi różnych kultur (w tym wyznań i religii) $\mathrm{i}$ ich zrozumienie.

We wczesnej edukacji dziecka, niezależnie od jego możliwości rozwojowych, które wyznaczają bądź ograniczają samokształtowanie tożsamości religijnej, proces ten - używając terminu Anthony'ego Giddensa: „refleksyjny projekt tożsamości” - już się rozpoczął (Giddens 2006). Co więcej: „Narrację tożsamościową trzeba kształtować, modyfikować i refleksyjnie podtrzymywać w kontekście gwałtownych zmian zachodzących w życiu społecznym w skali lokalnej i globalnej. Jednostka musi tak godzić na rozmaite sposoby zapośredniczone informacje ze sprawami lokalnymi, by połączyć w spójną w miarę całość swoje projekty na przyszłość i przeszłe doświadczenia" (Giddens 2006: 293).

Zdaniem Giddensa w epoce późnej ponowoczesności wykształciło się zjawisko instytucjonalnej separacji życia społecznego (w celu osiągnięcia bezpieczeństwa ontologicznego) od doświadczeń o fundamentalnym znaczeniu egzystencjalnym, co może być źródłem dylematów moralnych człowieka (Giddens 2006: 214-215). Jeśli w tej perspektywie zwrócić uwagę na brak w edukacji religijnej dziecka, a nawet w edukacji międzykulturowej, regionalnej i obywatelskiej treści odnoszących się do pluralizmu religijnego, to można je za Giddensem nazwać treściami wypartymi. Życie stwarza warunki do „powrotu wypartych treści" (Giddens 2006: 304) i potrzeby odbudowy wrażliwości na kwestie, które instytucje - w naszym wypadku szkoła i Kościół - rozmywają. Powrót wypartych 
treści i odbudowa wrażliwości na nie to niezmiernie istotne kwestie dla podmiotu odpowiedzialnego za autokreację tożsamości, w sytuacji bowiem społeczeństwa „po upadku kultury" - wobec słabych uwarunkowań społecznych - zadanie kreowania tożsamości spoczywa na jednostce (Szkudlarek 2008: 137). Należy żywić nadzieję, że problematyka pluralizmu religijnego, rozumianego jako wartość i zadanie wychowawcze, powróci do edukacji religijnej dzieci i młodzieży jako treści komplementarne i kompatybilne z ich doświadczeniem życiowym.

Niezmienne zadanie wszelkiej edukacji, również (a może przede wszystkim) wczesnej edukacji religijnej, polega na przygotowaniu do życia. Oznacza ono między innymi: „Pielęgnowanie umiejętności życia w zgodzie z poczuciem niepewności i ambiwalencji, w obliczu wielu punktów widzenia i braku nieomylnych i godnych zaufania autorytetów; musi oznaczać pogłębianie tolerancji na odmienność i poszanowania prawa do różnienia się, musi oznaczać wzmocnienie krytycznych i samokrytycznych umiejętności oraz odwagę niezbędną do przyjęcia odpowiedzialności za własne wybory i związane z nimi konsekwencje" (Bauman 2008: 169).

W procesie przygotowywania do życia, w socjalizacji pierwotnej i we wczesnej edukacji, dziecku towarzyszą znaczący inni - rodzice i nauczyciele. To do nich przede wszystkim adresuję przemyślenia na temat pluralizmu religijnego i potrzeby rozwijania otwartej tożsamości religijnej, będące treścią niniejszego artykułu. Mam nadzieję, że obraz świata konstruowany przez nich i przedkładany dziecku nie będzie pozbawiony wspaniałej różnorodności kulturowej i religijnej, lecz skonstruowany w kontekście pluralizmu jako wartości będzie wspomagał dziecko: w uczeniu się siebie, w określaniu swojego miejsca w świecie (Berger, Luckmann 1983: 210), w budowaniu tożsamości religijnej „przynależącej” do tego miejsca i świata „własnego”, ale wrażliwej i otwartej na „inne światy” i ludzi do nich przynależących. Jednak by słowa te nie miały życzeniowego charakteru, potrzebne jest wprowadzenie zmian ( $\mathrm{w}$ obszarze teleologicznym i treściowym) w edukacji religijnej w szkole publicznej, umożliwiających zdobywanie obiektywnej wiedzy o innych wyznaniach i opcjach światopoglądowych i kreowanie otwartych postaw wobec Innych. Taką szerszą perspektywę dydaktyczną umożliwiają modele edukacji religijnej konfesyjno-dialogiczny i wspomniany wcześniej ponadkonfesyjny, które nie tylko kształtują identyfikację wyznaniową, lecz również przygotowują ucznia na spotkanie z wielością poglądów i postaw.

Wczesna edukacja religijna ma kluczowe znaczenie w kształtowaniu tożsamości religijnej dziecka oraz postaw wobec inności i Innych w wymiarze kulturowym i religijnym. Pozwala na uformowanie się „zawiązków” tychże postaw, co do których spodziewamy się, że będą rozwijane i pogłębiane przez całe życie. Wczesna edukacja religijna nie powinna być zatem indoktrynacją, lecz okazją do budowania solidnego, ale wrażliwego podejścia wobec religii własnej i religii innych ludzi. 


\section{Literatura}

Armstrong K. (1998), Historia Boga. Cztery tysiące lat dziejów Boga w judaizmie, chrześcijaństwie $i$ islamie. Warszawa, Prima.

Bauman Z. (2008), Zindywidualizowane społeczeństwo. Gdańsk, Gdańskie Wydawnictwo Psychologiczne.

Berger P.L. (2007), Między relatywizmem a fundamentalizmem. „W Drodze”, 9.

Berger P.L. (2012), Further thoughts on religion and modernity. „Society”, 49(4).

Berger P.L., Luckmann T. (1983), Społeczne tworzenie rzeczywistości. Warszawa, PIW.

Brezinka W. (2005), Wychowanie i pedagogika w dobie przemian kulturowych. Kraków, WAM.

Davis A. (2010), Defending religious pluralism for religious education. „Ethics and Education", 5(3).

Dupuis J. (1999), Wprowadzenie do chrystologii. Kraków, WAM.

Dupuis J. (2002), Wszyscy zmierzamy do prawdy. Z o. Jacquesem Dupuis, teologiem, rozmawia Adam Boniecki. „Tygodnik Powszechny”, 30.

Dupuis J. (2003), Chrześcijaństwo i religie. Od konfrontacji do dialogu. Kraków, WAM.

Figl J., Fürlinger E., Hinterleitner M., Landstätter M. (2010), Katolickie spojrzenie na inne religie. W: U. Tworuschka (red.), Religie świata w dialogu. Poznań, Wydawnictwo Święty Wojciech.

Geffré C. (1996), Jedyność chrześcijaństwa a pluralizm religijny. „Znak”, 495.

Giddens A. (2006), Nowoczesność i tożsamość: „Ja” i spoleczeństwo w epoce późnej nowoczesności. Warszawa, Wydawnictwo Naukowe PWN.

Habermas J. (2009), Uwzględniając Innego. Studia do teorii politycznej. Warszawa, PWN.

Hryniewicz W. (1994), Tożsamość chrześcijańska dzisiaj. Od konfesjonalizmu do tożsamości otwartej. „Znak”, 5.

Hryniewicz W. (1997), Pedagogia nadziei. Medytacje o Bogu, Kościele i ekumenii. Warszawa, Verbinum.

Hryniewicz W. (2003), Wstęp do wydania polskiego: Odkrywać nieznane oblicze Boga. W: J. Dupuis, Chrześcijaństwo i religie. Od konfrontacji do dialogu. Kraków, WAM.

Kotusiewicz A.A. (1995), Dylematy pluralizmu w edukacji. W: J. Nikitorowicz (red.), Edukacja międzykulturowa. W kręgu potrzeb, oczekiwań i stereotypów. Białystok, TransHumana.

Kracik J. (2000), „Poza Kościołem nie ma zbawienia”. Ewolucja doktryny. W: S. Budzik, Z. Kijas (red.), Uniwersalizm chrześcijaństwa a pluralizm religii. Tarnów, BIBLOS.

Luckmann T. (1967), The Invisible Religion. The Problem of Religion in Modern Society. New York, Macmillan.

Milerski B. (1998), Religia a szkoła. Status edukacji religijnej w szkole w ujęciu ewangelickim. Warszawa, Chrześcijańska Akademia Teologiczna.

Obirek S. (2011), Umyst wyzwolony. W poszukiwaniu dojrzałego katolicyzmu. Warszawa, W.A.B.

Różańska A. (2015), Edukacja religijna młodzieży w warunkach pluralizmu religijnego w wybranych krajach Europy Środkowo-Wschodniej (Grupa Wyszehradzka: Polska, Czechy, Stowacja, Wẹgry) - studium porównawcze. Toruń, Wydawnictwo Adam Marszałek.

Różańska A. (2017), Edukacja religijna a otwarta tożsamość religijna. W: M. Humeniuk, I. Paszenda (red.), Między ekskluzja a inkluzja w edukacji religijnej. Wrocław, Uniwersytet Wrocławski.

Scalfari E. (2013), Papa Francesco a Scalfari: così cambierò la Chiesa "Giovani senza lavoro, uno dei mali del mondo". http://www.repubblica.it/cultura/2013/10/01/news/papa_francesco_a_ scalfari_cos_cambier_la_chiesa-67630792/http://www.repubblica.it/cultura/2013/10/01/news/ papa_francesco_a_scalfari_cos_cambier_la_chiesa-67630792/, 12.03.2019. 
Skeie G. (1995), Plurality and pluralism: a challenge for religious education. „British Journal of Religious Education", 17.

Słotwińska H. (2014), Pedagogika religii wobec pluralizmu religijnego. „Roczniki Teologiczne", 61(11).

Smith W.C. (1964), The Meaning and End of Religion, New York, New American Library.

Statystyki dotyczące migracji i populacji migrantów (2019). https://ec.europa.eu/eurostat/statistics-explained/index.php?title=Migration_and_migrant_population_statistics/pl, 11.03.2019.

Szkudlarek T. (2008), Dyskursywna konstrukcja podmiotowości (,,puste znaczace” a pedagogika kultury). „Forum Oświatowe”, 20.

Ziebertz H.-G. (2001), Religijność i wychowanie w świecie pluralistycznym. Kraków, WAM. 